MARIUSZ RUTKOWSKI

Uniwersytet Warminsko-Mazurski w Olsztynie

rutkow@uwm.edu.pl
DOI: http://dx. do1.org/10.17651/ONOMAST.61.2.9

Onomastica LXI/2, 2017

PL ISSN 0078-4648

\title{
NAZWY WŁASNE W STRUKTURZE METAFOR POJECIOWYCH
}

Słowa te matyczne: nazwy własne, teoria metafory, metafora pojęciowa, językoznawstwo kognitywne

\section{UWAGI WSTEPNE}

Teoria metafor pojęciowych jest jedną z podstawowych i najbardziej inspirujących w kognitywnym paradygmacie wspólczesnej lingwistyki. Prekursorzy myślenia o metaforze w kategoriach nie tyle wyszukanych ozdobników językowego wyrażania, co zwykłych i codziennych mechanizmów ludzkiego poznania i oswajania rzeczywistości - George Lakoff i Mark Johnson (1988) - jako pierwsi zwrócili uwagę na poznawczy (kognitywny) aspekt mówienia i myślenia metaforycznego, jako pierwsi też dali usystematyzowany wyklad na temat poznawczych walorów języka, zapoczątkowując w ten sposób caly nurt nowego postrzegania relacji między językiem, kulturą a rzeczywistością ${ }^{1}$. Podstawowe założenia teorii metafor pojęciowych sprowadzają się do dostrzeżenia nie tylko ogólnego związku myślenia metaforycznego z kategoryzacją rzeczywistości. Teoria ta thumaczy, w jaki sposób pojęcia bardziej ,oddalone" poznawczo (np. abstrakcyjne) ujmujemy w kategoriach pojęć „bliższych” poznawczo (konkretnych) na podstawie konceptualizacji podobieństwa między nimi - realnego lub tylko uzasadnionego kulturowo, a więc arbitralnego. Uświadamia też ona systemowy charakter konceptualizacji metaforycznych, a także ich uniwersalność i naturalność ${ }^{2}$.

${ }^{1}$ Pomijam z oczywistych względów wiele wątków związanych z początkami lingwistyki kognitywnej, jej ogólnymi założeniami i niezmiernie obecnie rozszerzonym zakresem. Na ten temat napisano w językoznawstwie tomy, a pamiętać należy, że obecnie tzw. kognitywistyka obejmuje nie tylko dziedzinę nauki o języku, ale również psychologię, filozofię i wiele innych nauk spolecznych i humanistycznych. O zalożeniach i najważniejszych tezach lingwistyki kognitywnej por. m.in.: Kardela (red.), 1994; Tabakowska, (red.), 2001).

${ }^{2}$ Nie miejsce tu na dokladne omawianie teorii metafor pojęciowych, jest ona dobrze znana nie tylko w kręgu badaczy zorientowanych kognitywnie. Przywołuję tu zatem jedynie podstawowe 
Metafora jest w tym ujęciu pojmowana jako jeden $\mathrm{z}$ mechanizmów językowych służących nie tylko realizacji określonych celów komunikacyjnych, ale również - a może przede wszystkim - celów poznawczych związanych z konceptualizacją i kategoryzowaniem rzeczywistości. Jest ona środkiem kognitywnego dotarcia do tych obszarów rzeczywistości (tzw. domen), które albo pozostają poza bezpośrednim zasięgiem zmyslów, albo są na tyle abstrakcyjne, rozmyte czy nieokreślone, że mogą być „oswojone” właśnie za pomocą metaforycznego użycia pojęć bliższych, prostszych poznawczo. W ramach teorii metafor pojęciowych mówi się, że elementy domeny źródłowej, a więc pojęcia bliższe i prostsze, mogą być w metaforycznym obrazowaniu odniesione czy przyporządkowane do elementów trudniejszej poznawczo domeny docelowej. Klasycznym przykladem z podstawowego dziela G. Lakoffa i M. Johnsona (1988, s. 26 i nast.) jest metafora SPÓR TO WOJNA, w której domena źródlowa WOJNA pozwala konceptualizować elementy domeny celowej (SPÓR): świadczą o tym takie wystąpienia językowe, jak: "Twoje twierdzenia nie dają się obronić”, "Zaatakowal wszystkie słabe punkty mojego rozumowania” czy „Zburzylem jego argumentację". Na podstawie analizy codziennych użyć językowych elementów z zakresu domeny źródlowej wnioskuje się więc, że cale pojęcie (domena) jest metaforycznie rzutowane (obrazowane) na domenę celową, co ułatwia - lub w ogóle czyni możliwą - jej konceptualizację.

W tym szkicu zostanie pokazane, w jaki sposób nazwy wlasne funkcjonują w strukturze takich właśnie metafor pojęciowych ${ }^{3}$. Podtrzymuję w tym ujęciu propozycję wyodrębniania metafor tzw. orientacyjnych oraz ontologicznych (Lakoff, Johnson, 1988, s. 36-54). Metafory pierwszego typu są postrzeżeniowo ufundowane na przestrzennej orientacji ludzkiego ciala i związanych z tym sposobów konceptualizacji przestrzeni na osi wertykalnej i horyzontalnej. Drugi typ metafor wiąże się z postrzeganiem abstrakcyjnych zjawisk (wydarzeń, uczuć, wyobrażeń, struktur spolecznych, właściwości umysłu itp.) w kategoriach rzeczy i substancji. Nazwy własne mogą funkcjonować w obu rodzajach metafor, przy czym w metaforach orientacyjnych występują w roli nośnika, a więc elementu domeny źródłowej, w metaforach ontologicznych z kolei zwykle same są reprezentantem pojęć, które ulegają metaforyzacji i są konceptualizowane za pomocą innych pojęć (są fragmentem domeny docelowej).

założenia i wykorzystuję tylko wybrane elementy, które są przydatne do przeprowadzenia założonej analizy. Dokładnie na ten temat zob.: Lakoff, Johnson, 1988; Jakel, 2003. Krytykę teorii przedstawia m.in. A. Pawelec (2006)

${ }^{3}$ Podobne spojrzenie na to zagadnienie zaprezentowalem wcześniej w pracy: Rutkowski, 2007. 


\section{NAZWY W METAFOR'ACH ORIENTACYJNYCH}

Jak wspomnialem, metafory tego rodzaju bazują doświadczeniowo na pozycji ludzkiego ciala i jego orientacji przestrzennej. Metafory takie nadają pewnym pojęciom orientację przestrzenną zgodną z ludzkim doświadczeniem czy to fizycznym, czy też kulturowym. Przykladowo: metafora SZCZĘSLIWY TO W GÓRE/ SMUTNY TO W DÓL („Czuję się uniesiony”, „Ktoś doznawal wzlotów i upadków”, "Czuję się dennie") oparta jest na ludzkiej postawie fizycznej, która jest wyprostowana w pozytywnych stanach emocjonalnych, a pochylona w stanach smutku i depresji (Lakoff, Johnson, 1988, s. 37).

Przyjrzyjmy sięjednej z takich metafor: WIĘCEJ TO W GORE/MNIEJ TO W DÓŁ. Jej baza doświadczeniowa wynika przede wszystkim z obserwacji zjawisk fizycznych - przy zwiększaniu liczby przedmiotów lub ich masy wzrasta też ich poziom, np. przedmioty ulożone jeden na drugim tworzą coraz wyższą konstrukcję, pojemniki napełnianie coraz większą ilością zawartości wypełniają się w górę itd. Fizjograficzne uksztaltowanie terenu narzuca taką kategoryzację, że poziom neutralny stanowi ziemia, po której czlowiek się porusza (można konwencjonalnie odnieść to do geograficznego pojęcia poziomu morza), a wszystkie formy, które wznoszą się ponad ten poziom, moga stanowić podstawę metafor oznaczających wysoki stopień jakiegoś stanu, zjawiska czy cechy. Użytecznymi elementami, które postrzeżeniowo wyodrębniają się na osi wertykalnej organizacji przestrzeni fizycznej i które mogą w związku z tym stać się reprezentantami domeny źródłowej mapowanej na abstrakcyjne domeny docelowe, są, z jednej strony, obszary wysoko i nisko polożone - góry (pasma, szczyty), a z drugiej strony, zlokalizowane nisko - depresje oraz rowy oceaniczne:

(1) „Szkice piórkiem” Andrzeja Bobkowskiego — absolutne Himalaje frazy i sposobu widzenia świata ${ }^{4}$.

(2) [...] superplayboye się wdzięczą, superdziewczyny robią z nimi, co chcą, gospodarze podpisują czeki politykom, gdzie spojrzysz, Himalaje dolarów.

(3) Pierwszy w historii polskiej opery wystawił tetralogię Wagnera „Pierścień Nibelunga”. To są Himalaje. W pewnym momencie zaczął się jednak otaczać marnościami, w myśl zasady, że na tle marności latwiej być gwiazdą.

(4) Zamieszkuje ona z ww. w strefie zdekomunizowanej, u podnóża Mount Everest niekompetencji.

(5) [...] aż do następnego dnia, kiedy pojawi się nowa instrukcja, ten nowy Mount Everest urzędniczej skwapliwości i woli przekształcania świata.

Powyższe przyklady to nie tylko tekstowe reprezentacje metafory WYSOKI STOPIEŃ TO GÓRA. Uwidacznia się w nich także stopniowalność cech/zjawisk

\footnotetext{
${ }^{4}$ Cytowane przykłady wystąpień, jeśli nie zaznaczono inaczej, pochodzą z Narodowego Korpusu Języka Polskiego (www.nkjp.pl).
} 
z domen docelowych — a więc odpowiednio: sztuki pisarskiej, bogactwa, opery, niekompetencji i biurokracji. Wzorce poznawcze reprezentowane przez omawiane nazwy górskie oznaczają tu zatem 'najwyższy stopień czegoś', 'maksymalne nasilenie jakiegoś zjawiska czy cechy'. Charakterystyczne jest również swoiste nakładanie się i przenikanie różnych schematów wyobrażeniowych, a także wzajemne oddzialywanie obu domen: źródlowej i celowej. Wartość poznawcza catej metafory jest efektem wspólpostrzegania wszystkich elementów biorących udział w procesie metaforyzacji. Doskonale to widać w tych przykładach, w których za pomocą nazwy Himalaje mówi się nie tylko o 'wysokim stopniu czegoś', ale też o 'trudnościach' w osiągnięciu celu — zgodnic z wzorcem poznawczym opartym na wyobrażeniu Himalajów i Mount Everestu przede wszystkim jako celów dzialalności sportowej, wspinaczkowej:

(6) Madonny z onkologicznego pokonywały Everest dwóch pięter i dysząc, przysiadały na brzegach lóżek, zanim w ogóle coś powiedziały, bo były najsłabsze i skazane na wymarcie.

(7) Opisane ubiory to oczywiście Himalaje mody, gdzie trudno się wspiąc i nie każdy musi to czynić.

(8) Żeglarski Everest, czyli opłynięcie przylądka Horn.

W przykładach (6)-(8) na zasadniczą metaforę WYSOKI STOPIEŃ TO GÓRA nakłada się dodatkowo skrypt WSPINACZKI oraz jeszcze bardziej uogólnione, wynikające $\mathrm{z}$ niego znaczenie TRUDNOŚCI (DO POKONANIA). Motyw trudności bazuje na powszechnym i utrwalonym kulturowo wzorcu poznawczym związanym z pokonywaniem przez człowieka terenów górskich, zgodnie z którym im wyżej, tym stopień trudności wzrasta ${ }^{5}$. Himalaje są w tym wzorcu odzwierciedleniem największych trudności, a ich zdobycie jest świadectwem najwyższego kunsztu, łączącym się z takimi społecznymi wartościami, jak sukces, uznanie, sława. Tak uogólniony schemat wyobrażeniowy jest na tyle uniwersalny, że może być z powodzeniem wykorzystany w zasadzie we wszystkich kontekstach związanych $\mathrm{z}$ pojęciem trudności, wynikających z działalności czlowieka w jakiejkolwiek dziedzinie. W tym sensie nie byloby bezzasadne np. twierdzenie, że „Prace Marii Malec to Himalaje antroponomastyki” albo też: „Profesor Malec w swych analizach językoznawczych niejednokrotnie zdobyla Mount Everest, czym zapisala się na trwale w historii polskiej onomastyki".

Co ciekawe, brak w zasadzie innych niż „himalajskie" przykładów metaforycznego odwzorowania przestrzeni górskiej w omawianym tu modelu poznawczym. Teoretycznie można sobie wyobrazić (i być może takie wystąpienia istnieją) przykłady wykorzystania nazw lokalnych, np. Tatr czy Alp, Rysów czy

\footnotetext{
${ }^{5}$ Warto na marginesie zwrócić uwagę także na metajęzykowy poziom omawianych zjawisk: oto bowiem w warstwie pisania (neutralnego) o omawianych metaforach nieustannie pojawiają się metaforyczne określenia, oparte na podstawowej metaforze WIECCEJ TO GÓRA: stopień trudności wzrasta, największe (najwyższe) trudności etc.
} 
Mont Blanc, nie są one jednak potwierdzone w korpusie językowym. Wydaje się, że jako lokalne wzorce najwyższego stopnia nie mają one charakteru uniwersalnego, nie są w związku z tym dobrym potencjalnym nośnikiem metafor odnoszących się do tego wlaśnie superlatywnego wymiaru. W globalnym, ziemskim wymiarze to wlaśnie Himalaje i Mount Everest wyznaczają górną granice, ale też i ludzką „miarę" - to, co ziemskie, normalne, zwyczajne, poznawalne i doświadczalne. Przekroczenie ziemskiej miary to przekroczenie stanów ludzkich granic, o czym świadczą takie wyrażenia, jak: coś/ktoś jest nie z tej ziemi, coś jest dla kogoś kosmosem, coś jest z Księżyca, to jest księżycowa teoria itp. Nazewniczym przekładem takiego wykraczania poza ziemskie limity jest jednostka Olympus Mons, wykorzystana w wypowiedzi (9):

(9) $[\ldots]$ smarkacz za kierownicą z resztek moskwicza pluje na nich nienawistnie i krzyczy: - Himalaje arogancji! A nie widzi, że sam się wrypał na Olympus Mons (góra na Marsie $25 \mathrm{~km}$ wysokości) arogancji. Bo jest jak z Marsa, calkowicie jakby izolowany od spraw ludzi żyjących na tej planecie („Rzeczpospolita”, 2005, 24 IX).

W wypowiedzi (9) pojawia się wyrażenie Himalaje arogancji, które jest jednym z kilku dość powszechnych konkretyzacji potencjalnej jednostki leksykalnej Himalaje (czegoś), gdzie miejsce walencyjne wypelniane jest nazwami stanów emocjonalnych lub innych abstrakcyjnych domen. Obok Himalajów arogancji mamy jeszcze Himalaje absurdu czy Himalaje glupoty, stosunkowo mocno reprezentowane w dyskursie publicystycznym.

W ramach metafory WYSOKI STOPIEN TO GÓRA/NISKI STOPIEN̉ TO DÓŁ realizuje się też obrazowanie stanów niskich. Wzorcem poznawczym stopnia nạjniższego jest jednostka Rów Mariański, odnosząca się prymarnie do najniższego zmierzonego miejsca na Ziemi, rowu oceanicznego w zachodniej części Oceanu Spokojnego. Podobnie jak w przypadku Himalajów/Everestu, tak i tu nie ma miejsca na inne, pośrednie obiekty stanowiące potencjalny wzorzec 'niskości' metafory orientacyjne uwidaczniają, poza wyrazistymi prototypami przestrzeni wertykalnej, również sklonność do operowania biegunowymi, skrajnymi wartościami. Ujawniają ludzką skłonność do hiperbolizowania rzeczywistości:

(10) Pilkarski Rów Mariański. Dziewiątego sierpnia ligowi pilkarze znów wybiegną na boiska. Nie zanosi się, żeby w tym sezonie było lepiej z poziomem meczów, liczbą kibiców na trybunach i bezpieczeństwem na stadionach („Rzeczpospolita”, 1997, 7 VIII).

(11) Rów Mariański. Bez emocji, przy malym zainteresowaniu inwestorów, kursy akcji nadal spadają. [...] Rynek obniza się niczym batyskaf w równym, szybkim tempie („Gazeta Wyborcza", 1994, 22 VI).

(12) Coś czuję, że nas rozjadą aż nie miło - a będzie to boleć tym bardziej, że to Wisła... I do tego daleka od formy - ale jeżeli oni to dno to my chyba jesteśmy Rowem Marianskim (legia net, dostęp 17 VI 2017).

(13) To nie dziura budżetowa, to Rów Mariański (solidarnosc-szczecin-enea.pl, dostęp 17 VI 2017). 
Metafora Rowu Mariańskiego wpisuje się w ogólniejszy schemat, odwolujący się do przenośnie pojmowanego dna: dno jako najniższy możliwy poziom jest produktywne zwlaszcza w domenach stanów psychicznych i emocjonalnych, samopoczucia czy wartościowania. Świadczą o takim obrazowaniu jednostki w rodzaju: cośjest denne, coś jest dnem, ktoś/coś znalazlo się na (samym) dnie. Rów Mariański jawi się w tym kontekście jako prototyp najniższego poziomu, a w odniesieniu do stanów emocjonalnych - jako odpowiednik najgorszego samopoczucia, najbardziej skrajnych emocji negatywnych. Piszą w ten sposób o swoich emocjach autorzy blogów internetowych:

(14) Miewam dołki (a raczej Rowy Mariańskie) psychiczne, ktỏre zazwyczaj kończą się stuchaniem deprymujących piosenek i/lub wykrzyczeniem wszystkich wątów (paoolinka.blog.onet. pl; dostęp 17 VI 2017).

(15) Teraz to są już tylko dołki. Na początku to byly Rowy Mariańskie, ale teraz to tylko male kotliny, depresje, przez które i tak mi smutno jest (love-me-tender.blog.onet.pl; dostęp 17 VI 2017). (16) Wznoszący się na wyżyny ekscytacji i wpadający w Rowy Marian̉skie chwilowego zwątpienia. Życiowi ekstremiści (trialuser.blog.onet.pl; dostęp 17 VI 2017).

Obydwa wzorce poznawcze maja jedną cechẹ wspólną: są mianowicie interpretowane jako wyznaczniki stopnia najwyższego, największego nasilenia jakiejś cechy czy zjawiska, i to bez względu na wartościowanie (choć intuicja mogłaby podpowiadać, by Everest czy Himalaje byly odnoszone raczej do wartości pozytywnych, a Rów Mariański do negatywnych). Natknąć się można na wypowiedzi, w których obie nazwy odnoszą się do tych samych domen, czy nawet pojęć, z tym samym pragmatycznym nacechowaniem:

(17) Czarnecki o Wałęsie: Mount Everest hipokryzji (wiadomosci.dziennik.pl).

(18) Brudziński, odnosząc się do ostatnich lat rządów koalicji PO-PSL, stwierdził, że hipokryzja PO jest w i el ka jak Rów Mariański (wiadomosci.onet.pl; dostęp: 17 VI 2017)

Takie wyabstrahowanie jednej cechy — najwyższego/najniższego stopnia czegoś - jest podstawą dalszego uogólnienia, które pozwala obie omawiane jednostki przeksztalcić w, ,językowy intensyfikator" (Chlebda, 2002, s. 13) o identycznym znaczeniu.

\section{NAZWY W METAFORACH ONTOLOGICZNYCH}

W projekcji metaforycznej jest w zasadzie regułą, że abstrakcyjne domeny docelowe są konceptualizowane za pomocą bardziej konkretnych i jasno

\footnotetext{
${ }^{6}$ Ostatni przykład pod względem językowym jest porównaniem, które jednakże można traktować w stosunku do metaforyzacji jako operację wstępną. Najważniejsza jest dla naszych rozważań tożsamość znaczeniowa i - w omawianych dwu przykladach — nawet referencyjna, tj. odniesienie do najwyższego stopnia hipokryzji.
} 
ustrukturyzowanych oraz latwiejszych postrzeżeniowo domen źródłowych (Jäkel, 2003, s. 28). Nazwy wlasne wpisują się w wiele tego typu metaforycznych odwzorowań, i to zarówno jako elementy domen docelowych, jak i źródlowych. W funkcji prototypowych reprezentantów domen źródlowych nazwy pojawiają się na zasadzie bardzo szczególnego typu metafor, w których dochodzi do jednoczesnego przesunięcia na zasadzie metonimii oraz obrazowania typu metaforycznego. Mechanizm takich metafor - nazywanych niekiedy metaftonimiami (Goosens, 1990) ${ }^{7}$ — opiera się na dwóch operacjach kognitywnych: rzutowaniu pierwszego stopnia w obrębie tej samej domeny (metonimia), a następnie rzutowaniu między dwiema domenami (metafora) ${ }^{8}$. W przypadku nazw użytych w funkcji nośnika metafor pojęciowych jest to uzasadnione i wydaje się konieczne - nazwy jako językowe znaki pojedynczego, niepowtarzalnego denotatu nie mają możliwości reprezentowania całej domeny bezjakiegoś „specjalnego" rozszerzenia zakresu. To rozszerzenie, czy też może lepiej uogólnienie, dokonuje się właśnie na zasadzie metonimii. Rozpatrzmy przykłady:

(19) Dzisiaj jest nasze Waterloo. Napoleon nie dojrzał głębokiego rowu na polu bitwy, a ja nie przewidziałem pomylki pana profesora. Stąd pochodzi nasza sromotna klapa.

(20) I tak jak Napoleon, tak każdy z nich ciągle wraca do swojego Waterloo i wygrywa w głowie nieodwołalnie przegraną bitwę.

(21) Od Waterloo kenijskiej opozycji minęlo pięć lat.

(22) Sto dni prezydentury Kwaśniewskiego minęlo bez Waterloo.

(23) Podpisanie „paktu stabilizacyjnego" z Samoobroną i LPR nie oznacza jednak, że Kaczyński unikną swojego Waterloo. Tylko je odroczył.

Nazwa Waterloo jest w powyższych wystapieniach wykorzystana dwustopniowo: po pierwsze, nastapiło metonimiczne przypisanie jej określonego wydarzenia (metonimia MIEJSCE ZA WYDARZENIE), tj. przegranej wojsk Napoleona z 18 czerwca 1815 r., która stała się przyczyną ostatecznej porażki cesarza Francuzów i powodem jego abdykacji. Dzięki takiemu przesunięciu nazwa miejsca może funkcjonować w znaczeniu wydarzenia (np. w wypowiedzi „Po Waterloo Napoleon się już nigdy nie podniósl'). Poza tym metafora pozwala przyporządkować tę nazwę do innych wydarzeń o podobnych postrzeżeniowo cechach (a więc majacych znamiona 'całkowitej klęski kogoś/czegoś'), jak to ma miejsce w wystapieniach (19)-(23). Nazwa wlasna pojawia się w metaforach

${ }^{7}$ Pisalem na ten temat w osobnym tekście, por. Rutkowski, 2008

${ }^{8} \mathrm{~W}$ kognitywnych teoriach języka różnicę między metonimią a metaforą wyznacza na ogół wlaśnie granica domeny: obrazowanie wewnątrz jednej domeny jest traktowane jako metonimia (o bardzo różnych typach i modelach), a rzutowanie pomiędzy domenami jest traktowane jako metafora. Na temat kognitywnych teorii metonimii por. np. Goosens, 1990; Radden, 2000, także uwagi w: Rutkowski, 2007, s. 59-84. 
pojęciowych w roli nośnika wówczas, gdy rzutowanie metaforyczne jest poprzedzone wewnątrzdomenowym przesunięciem metonimicznym ${ }^{9}$ :

domena 1

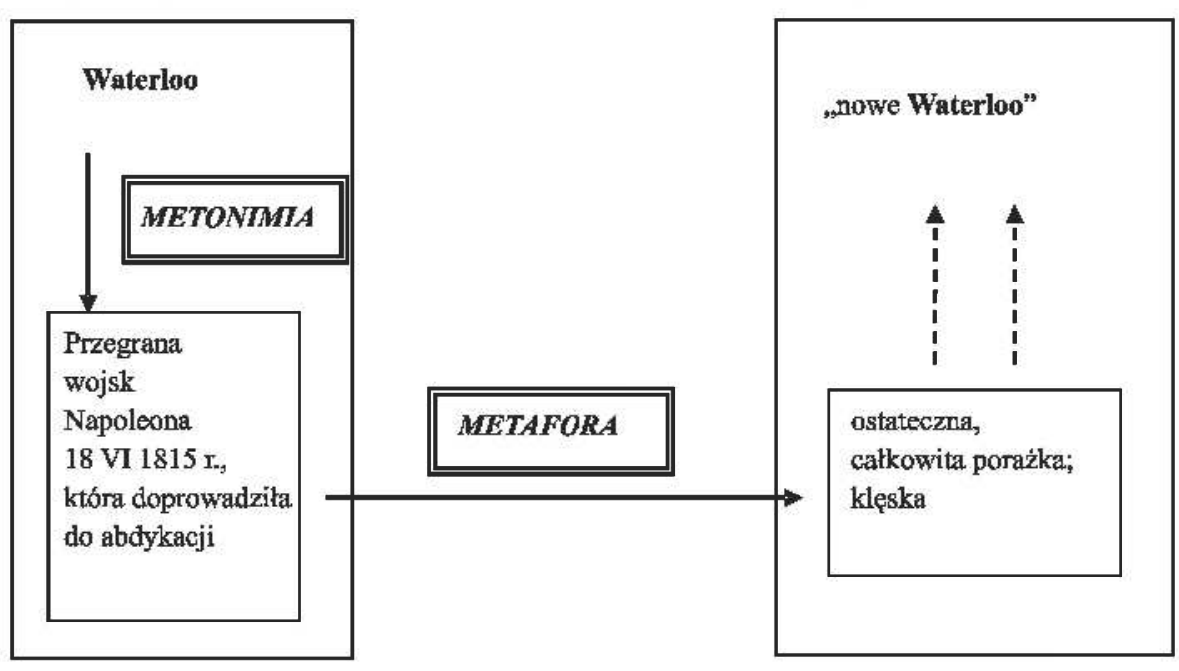

Związek metonimii i metafory (metaftonimia) na przykładzie nazwy Waterloo

Inaczej jest, gdy nazwa reprezentuje domenę docelową, abstrakcyjną, która sama jest metaforycznie ujmowana $w$ kategoriach zjawisk konkretnych. Zachowany zostaje wówczas podstawowy związek denotacyjny, ale metaforyzacji podlega cala domena, do której denotat nazwy należy. Rozpatrzmy kategorię nazw państw. Państwo jest definiowane w slowniku ${ }^{10}$ jako 'organizowana

${ }^{9}$ Tego rodzaju użycia nazw wlasnych są określane w teorii literatury mianem antonomazji. Jest to jeden z tzw. tropów, przy którego interpretacji metafora i metonimia mają równy udział: „Metafora i metonimia spotykają się tu i niejako na siebie nakładają. Nakładają nie w sensie upodobnienia funkcji, lecz w sensie tożsamości materialnej ich nośnika językowego. [...] Metafora stawać się może wypadkiem szczególnym metonimii, metonimia zaś - alternatywną interpretacją metafory" (Dobrzyńska, 1992, s. 28, 38). W niektórych ujęciach lingwistyki kognitywnej widzi się rzecz podobnie, postulując raczej nie tyle rozbieżności i odrębności w postrzeganiu obu zjawisk, co raczej widzenie ich jako różne przypadki tego samego procesu mentalnego. Co dla nas szczególnie ciekawe, metaftonimie w rodzaju tu omawianych stanowią środek tak pojmowanego continuum: ,[...] tradycyjny rozdział między metonimią a metaforą nie może byc̉ utrzymany. Klasyczne pojęcia metonimii i metafory są raczej postrzegane jako prototypowe kategorie na krańcach, biegunach continuum procesu rzutowania. Środek tego continuum wyznaczają metafory bazujące na przesunięciu metonimicznym, które jednocześnie wyjaśniają - dostarczając doświadczeniowej motywacji metafor - specyfikę przejścia metonimii w metaforę" (Radden, 2000, s. 105).

${ }_{10}$ Przytoczona definicja pochodzi $\mathrm{z}$ internetowego słownika języka polskiego PWN, por. sjp.pwn.pl/slownik (dostęp 17 VI 2017). 
politycznie społeczność zamieszkująca określone terytorium, mająca swój rząd i swoje prawa' i jako takie stanowi dość odległe, niedające się poznać zmysłowo i doświadczeniowo pojęcic. Należy więc ono do domeny abstrakcyjnej INSTYTUCJE SPOŁECZNE, konceptualizowanej metaforycznic, a jedną z najbardziej rozpowszechnionych metafor odnoszących się do tej domeny jest metafora PAŃSTWO TO CZLOWIEK. Ta najbardziej ogólna formula zawiera - zgodnie z całościowym i systematycznym charakterem metafor pojęciowych w ogóle wiele bardziej szczególowych przesunięć. Typowe dla tego rodzaju metafor jest bowiem to, że zapewniają one ,[...] somatyczno-biofizyczne podstawy poznania poprzez wsteczne powiązanie myślenia abstrakcyjno-pojęciowego z postrzeganiem zmyslowym, gwarantując tym samym spójność oraz jednolitość naszego doświadczenia" (Jakel, 2003, s. 34). W ten sposób nadrzędna przytoczona formula metaforyczna aktualizuje się w calym szeregu bardziej uszczególowionych metafor, odnoszących się do wybranych aspektów funkcjonowania państwa i postrzegania go w kategoriach wybranych aspektów odnoszących się do życia czlowieka. Życie czlowieka dostarcza calościowego modelu/wzorca poznawczego, na którym opiera się postrzeganie państwa, i w ten wlaśnie model/wzorzec wpisuje się caly system innych metafor pojęciowych. Zanim jednak przejdziemy do rozpatrywania tych bardziej uszczególowionych schematów wyobrażeniowych, przyjrzyjmy się przykładom ilustrującym nadrzędną metaforę PAŃSTWO TO CZEOWIEK.

Postrzeganie państwa w kategoriach czlowieka pozwala opisywać wiele zjawisk z zakresu ekonomii, geopolityki czy społecznego zorganizowania przy użyciu odniesień do stanów psychicznych czlowieka - tak rozpatrywane państwo ma określone motywacje, żywi uczucia, myśli, ma typowe dla czlowieka cele i potrzeby:

(24) Rosja c z uj e potrze bę związania się za pomocą Chin ze strukturami światowego systemu finansowego.

(25) Rosja pogodzila się z wejściem Polski do N'ATO, ale podejmuje dzialania, które mają opóźnić ratyfikację w parlamentach europejskich decyzji o rozszerzeniu Sojuszu (,Gazeta Wyborcza", 1997, 7-8 VI)

(26) Jeśli będzie to konieczne, w ciągu nadchodzących dni lub tygodni Francja n i e $\mathrm{za}$ wa ha si ę przywrócić tymczasowej kontroli na granicach.

Charakterystyczne są te metafory, w których odzwierciedla się postrzeganie relacji międzypaństwowych na podobieństwo relacji międzyludzkich. Tego typu obrazowanie jest bardzo rozpowszechnione, a jego siła wyobrażeniowa jest pochodną — z jednej strony - wysokiego stopnia abstrakcji w odniesieniu do stosunków międzynarodowych, a z drugiej - dużej bliskości i operatywności wzorca poznawczego (każdy czlowiek wchodzi w rozmaite relacje $\mathrm{z}$ innymi, doświadcza różnego typu emocji z tym związanych). Państwa w takim meta- 
forycznym obrazowaniu żywią do siebie uczucia, kłócą się, obrażają, walczą ze sobą, wspólpracują, porozumiewają się, zawierają sojusze — wykorzystują caly potencjal bazowej metafory personifikującej pojęcie państwa ${ }^{11}$ :

(27) A wersalskie poniżenie Niemiec i próba ich lekceważenia - przypomnę - do dobrych rzeczy nie doprowadziły („Gazeta Wyborcza”, 1998, 23 X).

(28) S zan $\mathrm{taż}$ wobec Mińska. Rosja u derz a w Bialoruś gazem: Gazprom chce czterokrotnie podnieść ceny gazu dla Białorusi („Rzeczpospolita”, 2006, $31 \mathrm{~V}$ ).

(29) Chiny o b raziły się na Koreę Pólnocna (,Wprost”, 2012, 18 IV).

(30) 30 czerwca zeszlego roku Ameryka rzu ciła wyzwani e Japonii i to nie byle jakie! (kawerna.pl).

(31) Rosja i Iran u z go d n iły te r m in a r z dostarczania paliwa do pierwszej irańskiej elektrowni nuklearnej w Buszerze („Gazeta Wyborcza”, 2007, 6 IX).

(32) Rosja porozumiał a się z Chinami w sprawie gazu (polska-azja.pl).

Konceptualizacja państwa jako czlowieka daje podstawy do wielu uszczególowień i pozwala w związku z tym wyodrębnić wiele pochodnych metafor, systemowo wywodzących się z omawianej metafory nadrzędnej. Pierwszą z takich „derywowanych" metafor jest POCZĄTEK TO NARODZINY (Lakoff, Johnson, 1988 , s. 100) oraz KONIEC TO ŚMIERĆ. O początkach państwa mówi się zatem jako o narodzinach, a koniec często jest porównywany do stanów agonalnych:

(33) Tymczasem po raz kolejny świętujemy n a r o dzi ny Polski socjalistycznej. 22 lipca 1944 roku podpisano w Lublinie Manifest PKWN. Dzisiejsza strona kultury niech będzie holdem dla ludzi sztuki socjalistycznej, ludzi ciężkiej roboty („Gazeta Wyborcza — Trójmiasto”, 2001, 21-22 VII)

(34) 2 lipca 1944 r. rozplakatowano na murach Chelma i okolic szumny "Manifest PKWN", naprawdę spreparowany na moskiewskim Kremlu dwa dni wstecz, a przez 45 lat PRL-u opiewany w namolnej propagandzie jako niemal po c z ę c i e Polski Ludowej (opcja.pop.pl; dostęp: 17 VI 2017).

(35) PiS już trzy razy oglaszal n a rodzi ny $I V R P$ i za każdym razem okazywało się, że aby urzeczywistnić tę wizję, konieczne jest poszerzenie zakresu władzy (www.pb.pl; dostęp 17 VI 2017).

(36) Z coraz większym rozbawieniem przyglądam się a g o $n$ i i Najjaśniejszej nam panującej $I I I$ RP (oceania.salon24.pl; dostęp 17 VI 2017).

(37) Czy Irak u m i e r a na próżno („,Gazeta Wyborcza”, 2006, 27-28 X).

Innym uszczególowieniem nadrzędnej metafory ontologicznej jest postrzeganie rozwoju państwa jako ruchu do przodu, a stagnacji i recesji — jako braku ruchu lub cofania się. Schemat wyobrażeniowy dostarcza zarówno obrazowania poruszającego się w różnorodny sposób człowieka, jak i zawiera w sobie utrwalone językowo wyrażenia utożsamiające pojęcie rozwoju z poruszaniem się/ruchem ${ }^{12}$.

${ }^{11}$ Niektóre z poniższych przykladów opierają się na systemowej metonimii PAŃSTWO ZA RZĄD, która pozwala na stosowanie nazwy państwa w odniesieniu do rządów tego pan̉stwa (jest to jedno z uszczególowień metonimii REPREZENTANT ZA CAEOŚć cZy też jeszcze szerszej CZĘ̧Śc ZA CAEOŚć).

12 Por. liczne językowe dowody takiego postrzegania rozwoju: szybki rozwój, prześcignác w rozwóju, hamować rozwój, kierunek rozwóju, zastój itd. 
Metafora ROZWÓJ TO RUCH DO PRZODU, wpisana w kategoryzowanie państwa jako czlowieka, daje podstawy do wypowiedzi w rodzaju (38)-(41):

(38) Ameryka pędzi jak szalona - aż o 5,3 proc. wzrósł PKB Stanów Zjednoczonych w pierwszym kwartale tego roku („Rzeczpospolita”, 2006, $26 \mathrm{~V}$ ).

(39) Chiny pę d z ą najszybciej od 10 lat („Gazeta Wyborcza”, 2006, 19 VII).

(40) Rosja c o fa si ę na drodze demokracji - ostrzega przyszła komisarz Unii ds. stosunków zewnętrznych i polityki sąsiedzkiej Benita Ferrero-Waldner („Gazeta Wyborcza”, 2004, 6 X).

(41) Podczas gdy inne kraje reformują swoje gospodarki, Polska stoi w miejscu. Znaleźliśmy się na 75 . pozycji rankingu najbardziej przyjaznych przedsiębiorcom krajów (money.pl; dostęp 17 VI 2017).

Gdy metaforę związaną $\mathrm{z}$ ruchem do przodu powiążemy z omawianą nadrzędną PAŃSTWO TO CZLOWIEK, uwidocznimy dalsze konceptualizacje związane z konkretyzacją tego ruchu: człowiek najszybciej się porusza, prowadząc pojazdy mechaniczne, a najszybszy ruch do przodu realizuje się w różnego rodzaju wyścigach. Metafora wyścigu wpisuje się z kolei w schemat pojęciowy rywalizacji — tak więc na państwa patrzy się jak na zawodników biorących udzial w globalnym „wyścigu gospodarczym”:

(42) Czy Polska została prześcignięta? W obszernej notatce „Polska najbiedniejsza w Unii” („Rzeczpospolita”, 2004, 11 VIII), Jędrzej Bielecki napisał, posilkując się danymi Eurostatu, że prześcignęly nas w zamożności Estonia i Litwa, a za chwilę prześcignie nas Lotwa („Rzeczpospolita”, 2004, 13 IX).

(43) Od 4 lat Polska nie nadrabia już dystansu w poziomie rozwoju w stosunku do krajów „15”. Ponieważ w tym czasie inne państwa Europy Środkowej szybko poszły do przodu, w poszerzonej Unii Europejskiej nie będzie biedniejszego kraju niż Polska (,Rzeczpospolita", 2003, 10 XI).

Wspomniany schemat wyobrażeniowy związany z kierowaniem pojazdem mechanicznym ma swe realizacje tekstowe w licznych wystapieniach, w których dodatkowo uruchamia się skrypt RUCHU ULICZNEGO oraz TORU JAZDY:

(44) Europa na z a kręc i e, Polskan a zakrę c i e. Lista problemów, z którymi współczesna UE musi się zmierzyć, biorąc „europejski zakręt”, jest długa („Rzeczpospolita”, 2004, 29 V).

(45) Polskawrzucila wsteczny bieg! Zobaczymy, dokąd dojedziemy — ja myślę, że tylem w słup (eSanok.pl).

(46) Zi elone światlo dla Slowacji wcale nie było bowiem przesądzone.

Jak widać, metafora PAŃSTWO TO CZLOWIEK pozwala na calościowe, systemowe mówienie o abstrakcyjnym pojęciu panstwa tak, jak mówi się o czlowieku. Nazwy wlasne innych kategorii tworzących domenę INSTYTUCJE SPOLECZNE wykazują podobne właściwości w ramach realizacji tej samej metafory - wystarczy porównać nazwy organizacji spolecznych, partii politycznych, podmiotów gospodarczych i innych wytworów życia spolecznego i przywolać sposoby ich konceptualizacji (np. „PKP nie liczą się z pasażerami”, „PZNP wkroczył na drogę walki z kibicami”, „Wyczekujemy na pojednanie PiS i PO” czy „Bank 
PKO SA dostał lekkiej zadyszki"). Powszechność metaforyzacji antropocentrycznych nie jest zresztą niczym niezwyklym.

\section{PODSUMOWANIE}

Nazwy wlasne, jak zostalo pokazane, funkcjonują w strukturach metafor pojęciowych w ramach obu domen: źródlowej i docelowej. Są zatem, zjednej strony, reprezentantami pojęć konkretnych i to reprezentantami najbardziej wyrazistymi poznawczo, bo odnoszacymi się do jednostkowych, indywidualnych i niepowtarzalnych denotatów (Himalaje, Rów Mariański). Z drugiej strony, gdy posiadają referencję kategorialną z zakresu domen docelowych, stanowią glówny temat metafory i same ulegają metaforycznemu obrazowaniu, można by rzec: ukonkretnianiu. Ta druga wlaściwość wydaje się szczególnie frapująca: skoro nazwa o prymarnie jednostkowej denotacji ze swej natury ma najbardziej ukonkretnioną referencję, to w jaki sposób sama może podlegać ukonkretnieniu na zasadzie metaforycznego obrazowania przy użyciu pojęć ogólnych? W pytaniu tym kryje się jednak tylko pozonny — by nie rzec: naiwny — paradoks. Nazwy wlasne odnoszące się do kategorii z natury rzeczy abstrakcyjnych, takich jak państwo, instytucje, podmioty gospodarcze (a więc pewnych konstruktów społecznych w dużym stopniu konwencjonalnych) mają co prawda jednostkowe przyporządkowanie, ale w sensie pojęciowym ich denotaty nie przestają być oddalone konceptualnie, trudne doświadczeniowo, sensualnie nieokreślone. Konkretna, nawet jednostkowa referencja nie neguje ich kategorialnej abstrakcyjności, która jest niwelowana wlaśnie za pomocą metaforyzacji.

Nazwy uczestniczą, rzecz jasna, także w innych rodzajach procesów językowych o podłożu kognitywnym czy konceptualnym ${ }^{13}$. Brak systemowo przypisanego znaczenia leksykalnego (zwlaszcza w sensie nadawanym przez lingwistykę formalną czy strukturalizm) w żaden sposób nie czyni tych szczególnych znaków językowych niezdolnymi do współkonstruowania mechanizmów poznawczych. Pokazuje to, że nie jest istotne doświadczeniowo czy kognitywnie samo znaczenie, ale raczej odniesienie, referencja - czyli desygnat. To z desygnatem styka się sensualnie czlowiek i na podstawie tego zmyslowego poznania przenosi pewne jego cechy na inne, bardziej abstrakcyjne zjawiska czy pojęcia. Nazwy są tu w sytuacji szczególnej. Jako znaki jednodesygnatowe są poznawczo najbardziej wyraziste - zespól cech stanowiących podstawę metafory może być więc najostrzejszy, najbardziej konkretny. Jako pozbawione systemowego znaczenia

${ }^{13}$ Konstruują metafory różnego typu, współtworzą amalgamaty (stopy pojęciowe), przesunięcia metonimiczne itp.; por. na ten temat Rutkowski, 2007. 
są jednak poznawczo trudniejsze, bo wymagają zawsze znajomości wzorca, denotacji. Gdy odbiorca jest tego wzorca pozbawiony, ma zasadnicze trudności ze zdekodowaniem metafory. $Z$ tego powodu utrwaleniu językowemu podlegają tylko te metafory nazewnicze, które są mocno osadzone w kulturze, świadomości spolecznej oraz mające odpowiednio dużo potwierdzeń tekstowo-korpusowych. Mimo dużego potencjału poznawczo-konceptualnego nazw wlasnych wiele metafor $\mathrm{z}$ ich udzialem $\mathrm{w}$ roli nośnika ma w związku $\mathrm{z}$ tym charakter efemeryczny bądź ograniczony sytuacyjnie (kontekstowo). $Z$ tego też powodu tak nieliczne są nazwy własne w roli nośników metafor pojęciowych. Inną przyczynąjest sama natura takich metafor, które wykorzystują najbardziej wyraziste reprezentacje określonych pojęć - stąd obecność nazw geograficznych obiektów biegunowo zorientowanych na osi wertykalnego postrzegania przestrzeni. Interesujące byloby uzupelnienie poczynionych tu spostrzeżeń o nazwy z wymiaru horyzontalnego, być może jednostki takie jak Australia, Syberia czy jeszcze inne (por. powiedzenie ,gdzie Rzym, a gdzie Krym") stanowią prototypowe językowo odpowiedniki miejsc oddalonych, zróżnicowanych czy ustanawiających jeszcze inne, ciekawe pod względem konceptualnym opozycje.

\section{LITERATURA}

Chle bda, W. (2002). Polak przed mentalną mapą świata. Etnolingwistyka, 14, s. 9-26.

Dobrzyńska, T. (1992). Nazwy wlasne w użyciach tropicznych. Casus antonomazji. W: T. Dobrzyńska (red.), Studia o tropach. II. Wrocław: Ossolineum, s. 27-39.

Goosens, L. (1990). Metaphtonymy: The interaction of metaphor and metonymy in expressions for linguistic actions, Cognitive Linguistics, 1, s. 323-340.

Jakel, O. (2003). Metafory w abstrakcyjnych domenach dyskursu. Kognitywno-lingwistyczna analiza metaforycznych modeli aktywności umysłowej, gospodarki i nauki. Przeł. M. Banaś, B. Drąg. Kraków: Universitas.

Karde la, H. (red.) (1994), Podstawy gramatyki kognitywnej. Warszawa: Zakład Semiotyki Logicznej UW.

La k o f f, G., J o h n s o n, M. (1988). Metafory w naszym życiu. Przeł. T. P. Krzeszowski. Warszawa: PIW.

Narodowy Korpus Języka Polskiego, www.nkjp.pl (dostęp 17 VI 2017)

Pawel ec, A. (2006). Metafora pojęciowa a tradycja. Kraków: Universitas.

Radden, G. (2000). How Metonymic Are Metaphors?, W: A. Barcelona (ed.), Metaphor and Metonymy at the Crossroads: A cognitive perspective. Berlin-New York: Walter de Gruyter, s. 93-108.

Rutkowski, M. (2007). Nazwy własne w strukturze metafory i metonimii. Proces deonimizacji. Olsztyn: Wyd. UWM.

Rutkowski, M. (2008). Metafory motywowane metonimicznie (metaftonimie) na przykladzie nazw własnych. Białostockie Archiwum Językowe, 8, s. 95-104.

Tabakowska, E. (red.) (2001). Kognitywne podstawy języka i językoznawstwa. Kraków: Universitas. 
SUMMARY

PROPER NAMES AND THE CONCEPTUAL METAPHORS

The present paper examines the issue of conceptual metaphors related to proper names. According to the Lakoff'Johnson's theory, two types of metaphor are sustained - orientational metaphors and ontological metaphors. The author shows how proper names may be a part of source domains, as well as how they function within the new metaphorical expressions. Some examples from the Polish lexicon are discussed, e.g. the names of Himalaya, Mount Everest, Marian Ditch, Waterloo and the like. Some conceptual metaphors, such as the figuration of the state as a human being, and other sub-metaphors which can be derived from this, are also examined. Proper names may function within the metaphorical expressions due to their specificity, and because their denotata are closer to the human experience.

Key words: proper names, metaphor theory, conceptual metaphor, cognitive linguistics 